\title{
Obituaries
}

\section{Walter Somerville}

Leading cardiologist and former editor of Heart

Walter Somerville assisted at the UK's first cardiac catheterisation, performed by Paul Wood in 1948. For 20 years he edited the British Heart Journal, now simply Heart. He was consultant cardiologist at Harefield Hospital and the Middlesex Hospital, and senior lecturer at the Middlesex for 25 years, and was crucial to the success of cardiac surgery at both centres.

During the second world war he worked on chemical and biological weaponry, and remained on related committees for 20 years afterwards.

Walter Somerville was born in Dublin. From the Jesuit Belvedere College he went to University College Dublin, doing his clinical studies at the Mater Hospital. Feeling that medicine in Dublin was subject to excessive religious influence, he went to London. He was appointed as a clinical assistant at the Brompton Hospital in 1939, just as war broke out.

Somerville wanted to be a pilot in the Royal Air Force, but was steered into the Royal Army Medical Corps. He served on a troop ship before being moved to chemical and biological warfare duties at Porton Down. He was seconded to the Canadian Department of Defence and then, in 1943, the US chemical warfare unit. Working in the southwest Pacific, he assisted in top secret

\section{Maria Elisabeth Johanna (Marlies) Eenhuizen-Graham}

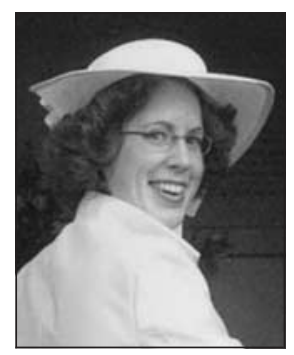

GP trainee Kelso Health Centre (b Barendrecht, Netherlands, 1976; q Leiden 2000), died from pneumonia on 5 February 2005.

Marlies became absorbed in the care of the most vulnerable people; those who are

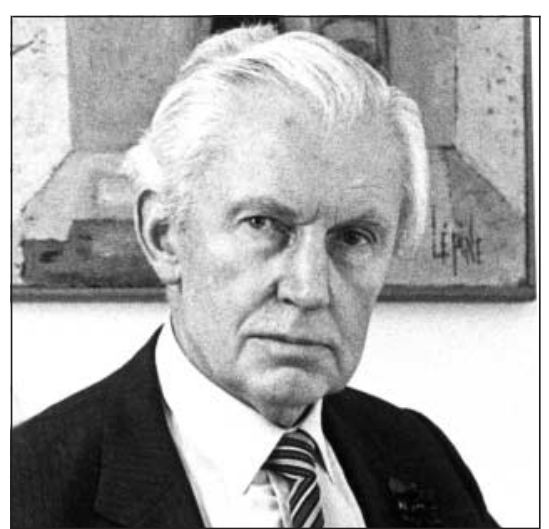

preparations for the invasion of Japan. During this experience he was badly burned.

His closest friend in the US army was George Merck, son of the drug company's founder, who suggested that the family firm could use Somerville's talents, but Somerville felt it was not for him. Shortly afterwards, in a Boston pub, a Metro Goldwyn Mayer talent scout noted his fine English voice and Irish good looks, and offered him a screen test. Fortunately for cardiology, Somerville refused.

Returning to England in 1946, he attended a refresher course at Hammersmith Hospital taught by the great cardiologist Paul

about to die. She was a warm, caring, and empathetic doctor who was always prepared to take that extra step closer to her patients to hold their hand, to deliver comfort, and to listen to their concerns. During her GP training at the Borders General Hospital, Marlies introduced an innovative programme for palliative care, which is being rolled out throughout south Scotland. She leaves a husband, Andrew. [AnDREw GRAHAM]

\section{John Adolf Riedel}

Former consultant obstetrician and gynaecologist Leicester (b Dutch East Indies 1923; q Edinburgh 1948), died from a heart attack on 29 May 2005.

John took posts in Edinburgh, London, and Sheffield before being appointed as
Wood. Jobs were hard to find for the "bulge" of demobbed doctors, but Wood was impressed by Somerville and appointed him as registrar, later making him a senior assistant at the National Heart Hospital. When Wood had a heart attack in 1962, aged 54, he wanted Somerville to look after him.

Though it was difficult for an Irish graduate to enter the closed shop of London teaching hospitals, he was chosen as consultant to the Harefield Hospital in 1952 and the Middlesex in 1954, and stayed at both hospitals until he retired. He also was a consultant to the army and Royal Air Force, looking after senior officers and the pensioners in the Chelsea Royal Hospital. He wrote 60 papers on infective endocarditis, emotions and the heart, mitral stenosis, and other topics.

Somerville was mugged badly in 1987 and the retinal bleeding this caused, combined with macular degeneration, made him completely blind for the last years of his life. He leaves a cardiologist wife, Jane Somerville; and four children. [CAROLINE RICHMOND]

Walter Somerville, former consultant cardiologist Harefield and Middlesex hospitals (b 1913; q University College Dublin 1937; $M D, C B E)$, died from heart failure on 20 July 2005.

consultant obstetrician and gynaecologist in Leicester. He liked prestigious cars. Later, as his practice grew, he studied for and obtained his yachtmaster's certificate and became part owner of the yacht Kiruna. It took a good deal of his spare time and organising ability to manage Kiruna's crewing and cruising. He acquired an apartment in Brittany, attending Kiruna's cruising area into the Bay of Biscay. John retired at 60 , feeling future NHS work would be unrewarding, but he went on to teach medical English to foreign doctors hoping to work in the United Kingdom. He leaves a wife, Val; a daughter; and a granddaughter. [MARTin Fisher]

Longer versions of these obituaries are available on bmj.com 